\title{
CREAM \\ Diversity and distribution of myxomycetes in western part of India, with special reference to the state of Gujarat
}

\author{
Vasava $\mathrm{AM}^{1}$, Koyani $\mathrm{RD}^{1}$, Singh $\mathrm{AP}^{2}$ and Rajput $\mathrm{KS}^{1}{ }^{\text {* }}$ \\ IDepartment of Botany, Faculty of Science, The Maharaja Sayajirao University of Baroda, Vadodara 290002, \\ 2 Chief Conservator of Forest, Wildlife Circle, Sardar Baug, Junagadh 362001, India
}

Vasava AM, Koyani RD, Singh AP and Rajput KS 2015 - Diversity and distribution of myxomycetes in the western part of India, with special reference to the state of Gujarat. Current Research in Environmental \& Applied Mycology 5(4), 382-389, Doi 10.5943/cream/5/4/9

\begin{abstract}
The occurrence and diversity of myxomycetes was surveyed in the state of Gujarat, western part of India. Earlier studies of the diversity of myxomycetes in Gujarat are almost completely lacking except for reports of the occurrence of Diderma cingulatum Nann.-Brem, Lepidoderma effusum Rokade \& Nanir, and Licea elloriana Nanir \& Rokade by earlier workers. In the present study, 12 species from 10 genera were collected, of which seven species belonging to six genera (Arcyria cinerea [Bull.] Pers., Arcyria denudata Fr., Ceratiomyxa fruticulosa [O.F. Müll.] T. Macbr., Cribraria cancellata [Batsch] Nann.-Bremek., Fuligo septica [L.] F.H. Wigg, Hemitrichia calyculata [Speg.] M. L Farr and Stemonitis axifera [Bull.] T. Macbr.) are reported for the first time from Gujarat. Further studies are warranted since Gujarat is known for its wide variety of climatic conditions and vegetation, ranging from moist deciduous forests to pure desert condition. There are likely to a number of additional species, and more extensive studies are required to complete the list of myxomycetes occurring within the state.
\end{abstract}

Keywords - Acellular slime moulds - diversity - Gujarat - myxobiota - protozoa - species list

\section{Introduction}

Myxomycetes shares unique features during different phase of their lifecycle which are characteristic to both plants (i.e. fungi) and animals. Therefore, earlier they have been classified in the kingdom Plantae (class Myxomycota) and the kingdom Animalia (class Mycetozoa). Phylogenetic analysis of highly conserved, elongation factor 1-alpha (EF-1 $\alpha)$ gene sequences of myxomycetes was carried out by Bauldauf \& Doolittle (1997) and concluded that they are not fungi. Motile, amoeboid stages (myxamoebae and plasmodia) and the motile swarm cells like animals forced Martin and Alexopoulos (1969) and Spiegel et al. (2004) to include this group in the Kingdom Protista of Class Eumycetozoa (Keller \& Everheart 2010). Currently this group is classified as Myxogastrids in the Super Class Amoebozoa and in the first rank Eumycetozoa (Adl et al. 2005).

Myxomycetes are acellular slime moulds and are characterized by amorphous, coenocytic protoplasmic mass during assimilative phase known as plasmodium which forms fruiting bodies during sporulating phase similar to fungi. They have been known for more than 350 years (Baba, 2012) and are commonly distributed throughout the world. Nearly 1000 species of myxomycetes have been reported from all over the world (Lado 2001). They occur in variety of environment including dead and 

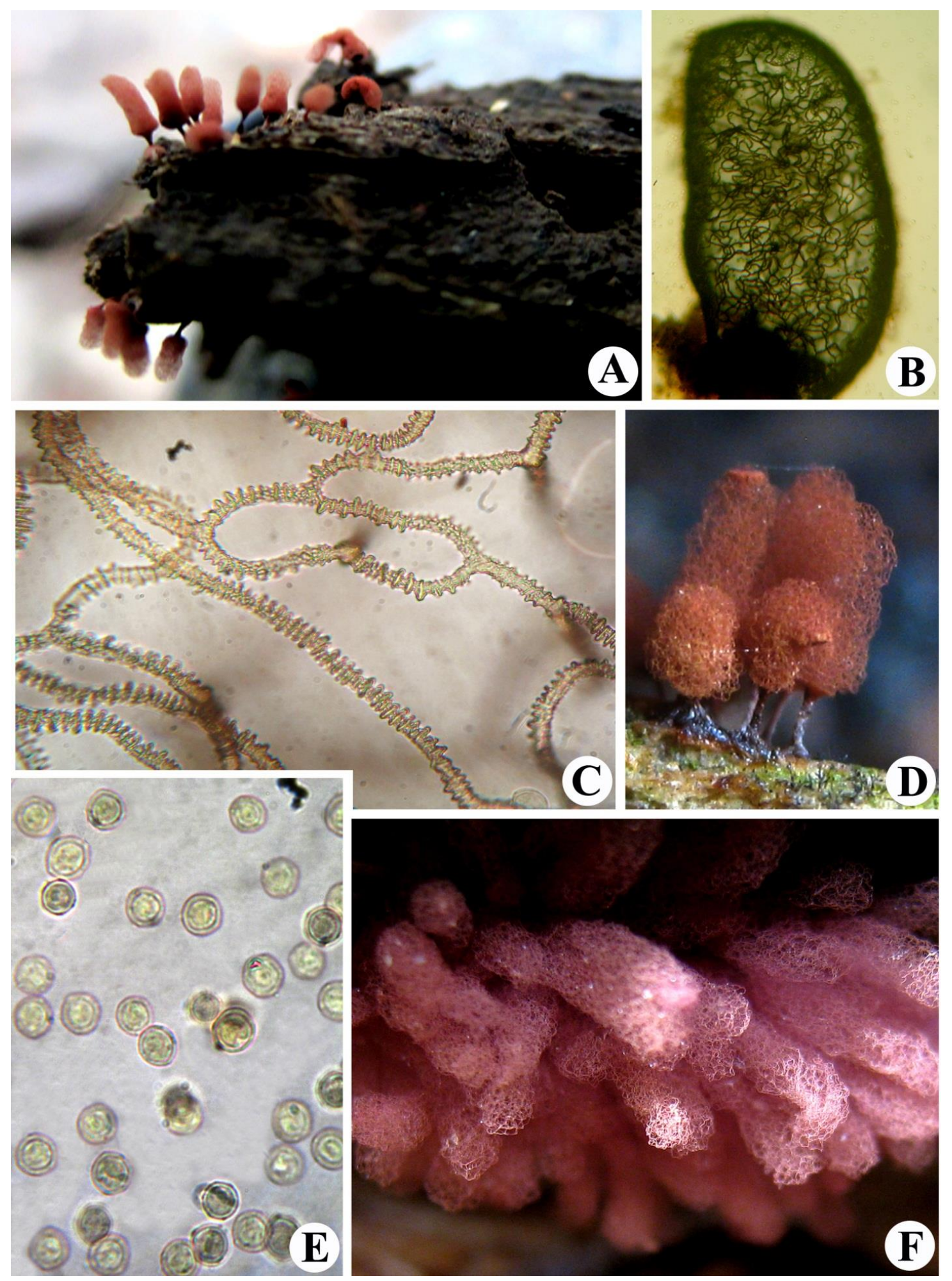

Fig. 1 - Arcyria denudata fruiting body (A), Enlarged view of sporotheca under microscope (B), Enlarged view of capillitium (C), Enlarged view of fruiting body (D), Spores (E), Overview of sporotheca $(\mathrm{F})$.

decaying wood logs, branches of the trees, dung and damp places, in moist and shady places etc. They have been widely studied worldwide and the important contributions are of those by Lodhi (1934), Farr (1962), Martin \& Alexopoulos (1969), Alexopoulos (1963, 1967), Thind (1977), Lakhanpal \& Mukherji (1981), Martin et al. (1983) and Ranade et al. (2012). However, there have been no previous studies on the myxobiota of Gujarat state. Therefore, the main aim of the present study is to document the diversity of myxomycetes in the state of Gujarat, western part of India. 

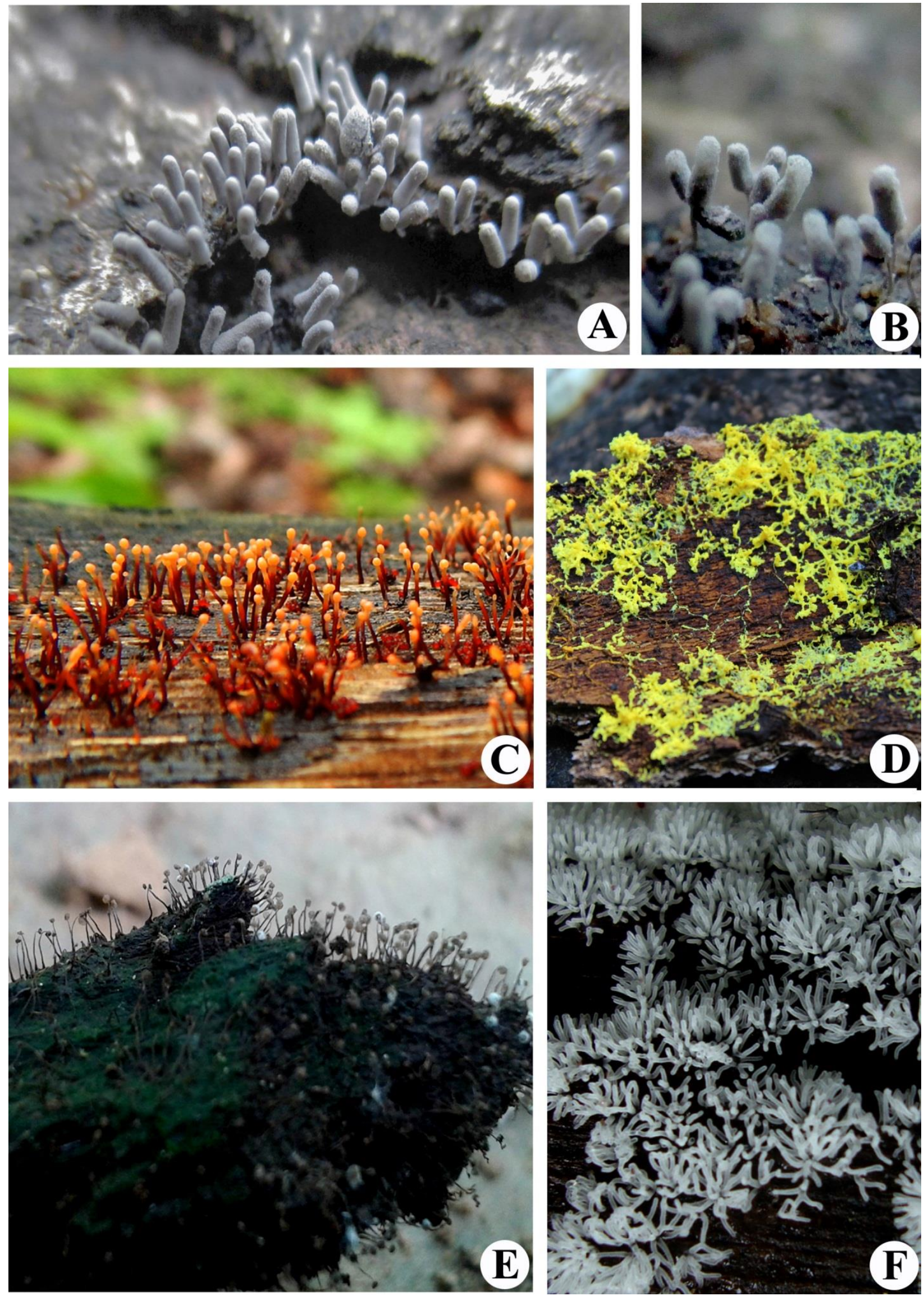

Fig. 2 - Fruiting bodies of Arcyria cinerea (A), Enlarged view of fruiting body of Arcyria cinerea (B), Hemitrichia calyculata (C), Fuligo septica (D), Cribraria cancellata (E), Ceratiomyxa fruticulosa (F). 

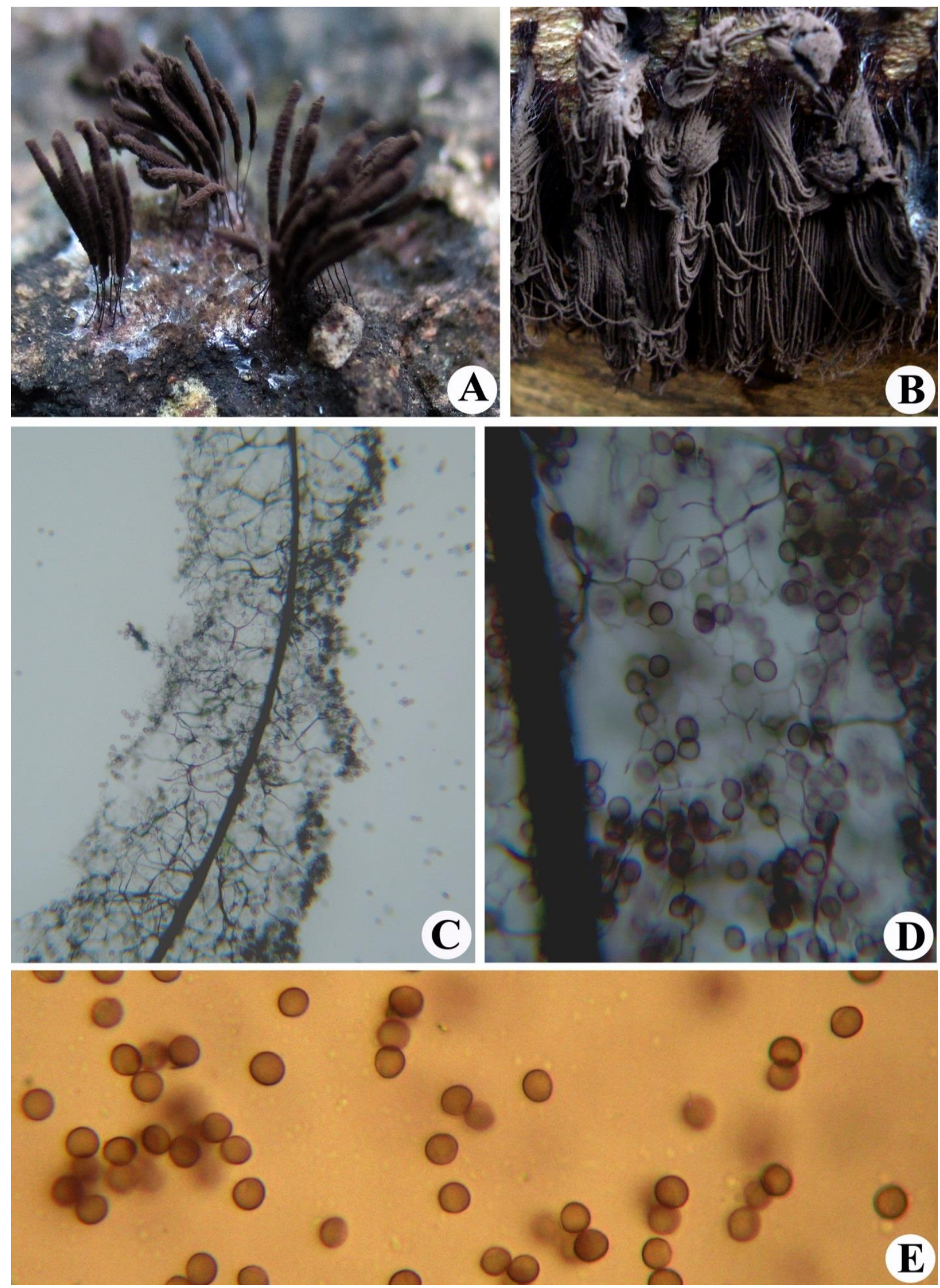

Fig. 3 - Fruiting bodies of Stemonitis axifera (A), Stemonitis fusca (B), Capillitium of Stemonitis axifera (C), Spore mass with columella of Stemonitis axifera (D), Spores of Stemonitis axifera (E). 
Table 1 List species collected from different forest and its distribution in Gujarat state

\begin{tabular}{|c|c|c|c|c|}
\hline Sr. No. & Species Name & Family & Location & References \\
\hline 1 & Arcyria cinerea (Bull.) Pers. & Arcyriaceae & $\begin{array}{l}\text { Dediapada, Girnar, Rajpipala, Ratanmahal, } \\
\text { Vadodara, Waghai }\end{array}$ & Present study \\
\hline 2 & Arcyria denudata Fr. 1851 & Arcyriaceae & Waghai, Rajpipla, Girnar & Present study \\
\hline 3 & $\begin{array}{l}\text { Ceratiomyxa fruticulosa (O.F. } \\
\text { Müll.) T. Macbr. }\end{array}$ & Ceratiomyxaceae & Ratanmahal, Vadodara, Dang & Present study \\
\hline 4 & $\begin{array}{l}\text { Cribraria cancellata (Batsch) } \\
\text { Nann.-Bremek. }\end{array}$ & Cribrariaceae & Vadodara & Present study \\
\hline 5 & $\begin{array}{l}\text { Diderma cingulatum Nann.- } \\
\text { Bremek. }\end{array}$ & Didymiaceae & Dang, Girnar, Dediapada & Ranade et al. 2009, Present study \\
\hline 6 & Fuligo septica (L.) F.H. Wigg & Physaraceae & Dang & Present study \\
\hline 7 & $\begin{array}{l}\text { Hemitrichia calyculata (Speg) } \\
\text { M. L Farr }\end{array}$ & Trichiaceae & Ratanmahal, Rajpipla & Present study \\
\hline 8 & $\begin{array}{l}\text { Lepidoderma effusum Rokade } \\
\text { \& Nanir }\end{array}$ & Didymiaceae & Dang, Girnar, Rajpipala & Ranande et al. 2009, Present study \\
\hline 9 & $\begin{array}{l}\text { Licea elloriana Nanir \& } \\
\text { Rokade }\end{array}$ & Liceaceae & Dang, Ratanmahal & Ranade et al. 2009, Present study \\
\hline 10 & $\begin{array}{l}\text { Physarum polycephalum } \\
\text { Schwein }\end{array}$ & Physaraceae & Dang, Baroda, Rajpipala & Rajput et al. 2015, Present study \\
\hline 12 & $\begin{array}{l}\text { Stemonitis axifera (Bull.) } \mathrm{T} \text {. } \\
\text { Macbr. }\end{array}$ & Stemonitidaceae & Baroda, Ratanmahal & Present study \\
\hline
\end{tabular}

\section{Material and methods}

Mature fructifications developed naturally on the substrata, plant debris including the bark of living trees, as well as on decaying bark, wood, leaves, and litter were gently collected along with the substratum and placed in plastic boxes. The morphological characteristic and photographs of fruiting bodies were recorded in their natural habitat with Cannon digital camera. After bringing the samples at laboratory, microscopic and macroscopic features of the specimens were determined by using Leica stereo zoom microscope. The morphological features such as shape of the fruiting body, its size and colour, spore shape and size, and stalk colour were recorded in the laboratory. The specimens were identified using the literature given by Martin and Alexopoulos (1969), Thind (1977), Lakhanpal \& Mukherji (1981) and Sesli \& Denchev (2008).

\section{Results and Discussion}

Recently Ranade et al. (2012) published the checklist of myxomycetes of India and recorded 373 species belonging to 50 genera belonging to 11 families. Extensive field studies during 2013-2014 resulted in the collection of 12 species belonging to 10 genera from the Gujarat (Fig. 1-3). All species of myxomycetes collected from the field are identified (Table 1) from which Diderma cingulatum Nann.-Brem, Lepidoderma effusum Rokade \& Nanir and Licea elloriana Nanir \& Rokade are recorded from Dangs forest by Ranade et al. (2012) during the study on myxomycetes of India. In contrast, 
Physarum polycephalum Schwein and Stemonitis fusca Roth. are reported in our previous study of fungal diversity of Gujarat (Rajput et al. 2015), whereas Arcyria cinerea [Bull.] Pers., Arcyria denudata Fr., Ceratiomyxa fruticulosa [O.F. Müll.] T. Macbr., Cribraria cancellata [Batsch] Nann.-Bremek., Fuligo septica [L.] F.H. Wigg, Hemitrichia calyculata [Speg.] M. L Farr and Stemonitis axifera [Bull.] T. Macbr., are reported for the first time from Gujarat.

Due to importance of myxomycetes in biological research (Keller \& Everheart 2010) this group has been studied extensively worldwide but similar information on their diversity in Gujarat is lacking. Recently, few studies on other groups of fungal diversity of Gujarat have been initiated but most of them are concentrated around the plant or human pathogens (Arya et al. 2008, Saxena \& Ratnthora 2009, Gajjar et al. 2011, Kumar et al. 2011, Bhavsar et al. 2012, Nagadesi \& Arya 2012, 2013, Nawal et al. 2012, Thaker \& Maharsh 2012, Assudani et al. 2013, Dhingani et al. 2013, Katara et al. 2013, Khan et al. 2013, Khokhar et al. 2013, Korat et al. 2013, Nasit et al. 2013, Panchal et al. 2013; Shah et al. 2013; Yadav et al. 2013) and documented 334 species while only five species of myxomycetes have been reported in previous study (Ranade et al. 2012, Rajput et al. 2015). Our extensive field work during the present study resulted in the collection of 12 species belonging to 10 genera from which seven species are additions to Gujarat state. Looking to the biogeography and variety of climatic conditions such as moist deciduous forest to pure desert conditions, there may be more number of species of myxomycetes in Gujarat. Therefore, further studies are warranted to document the diversity of the Gujarat state.

\section{Acknowledgements}

Authors are thankful to Gujarat Biodiversity Board for the financial support. Thanks are also due to Prof. (Dr.) K. D. Hyde (Editor in Chief) and anonymous reviewers for their critical comments on the manuscript.

\section{References}

Adl SM, Simpson AGB, Farmer MA, Andersen RA, Anderson OR, Barta JR, Bowser SS, Brugerolle G, Fensome RA, Fredericq SA, James TY, Karpov S, Kugrens P, Krug J, Lane CE, Lewis LA, Lodge J, Lynn DH, Mann DG, McCort RM, Mendoza L, Moestrup O Mozley-Standridge SE, Nerad TA, Shearer CA, Smirnov AV, Spiegel FW \& Taylor MFJR. 2005 - The new higher level classification of eukaryotes with emphasis on the taxonomy of protists. J. Eukar. Microbiop. 52, 399-451.

Alexopoulos CJ. 1963 - The Myxomycetes. Bot. Rev. 29, 1-78.

Alexopoulos CJ. 1967 - Taxonomic studies in the Myxomycetes - I. The genus Macbrideola. Mycologia 59, 103-116.

Arya A, Albert S, Nagdesi PK. 2008 - New and interesting records of Basidiomycetous fungi from Ratanmahal Wildlife Sanctuary, Gujarat, India. Mycol. \& Plant Pathol. 38, 221-226.

Assudani HJ, Pandya JM, Sarvan RR, Sapre AM, Gupta AR, Mehtam SJ. 2013 - Etiological diagnosis of microbial keratitis in a tertiary care hospital in Gujarat. Nat. J. Med. Res. 3, 6062 .

Baba H. 2012 - Myxomycetes of Mustafa Kemal University campus and environs (Turkey). Turk. J. Bot. 36, 769-777.

Baldauf SL, Doolittle WF. 1997 - Origin and evolution of the slime molds. Proc. Nat. Acad. Sci. 94: 12007-12012.

Bhavsar HK, Modi DJ, Sood NK, Shah H. 2012 - A study of superficial mycoses with clinical mycological profile in tertiary care hospital in Ahmedabad, Gujarat. Nat. J. Med. Res. 2(2), 160-164.

Dhingani JC, Solanki KU, Kansara SS. 2013 - Management of root rot disease [Macrophomina phaseolina (Tassi.) Goid] of chickpea through botanicals and oil cakes. The Bioscan 8(3), 739-74

Farr ML. 1962 - Arcyria cinerea and Arcyria pomiformis, revised. Mycologia 54, 516-520. 
Gajjar DU, Pal AK, Parmar TJ, Arora AI, Ganatra DA, Kayastha FB, Ghadadra BK, Vasavada AR. 2011 - Fungal scleral keratitis caused by Phomopsis phoenicicola. J. Clin. Microbiol. 49, 2365-2368.

Katara RS, Patel ND, Sinha M. 2013 - A Clinical Microbiological Study of Corneal Ulcer Patients at Western Gujarat, India. Acta Medica Iranica 51(6), 399-403.

Keller HW, Everheart SE. 2010 - Importance of myxomycetes in biological research and teaching. Fungi (3), 1-25.

Khan SR, Nirmal Kumar JI, Kumar RN, Patel JG. 2013 - Physicochemical properties, heavy metal content and fungal characterization of an old gasoline contaminated soil site in Anand, Gujarat, India. Environ. \& Expt. Biol. 11, 137-143.

Khokhar N, Mulla S, Shah L, Vaghela L. 2013 - Characterization of clinical isolates like bacteria and fungi from ocular infection. J. Infect. Dis. Lett. 2, 12-15.

Korat C, Chopada G, John P. 2013 - Studies on biodiversity of fleshy fungi in Navsari (South Gujarat), India. Intl. J. Biodiv. Conserv. 5(8), 508-514.

Kumar A, Pandya S, Kavathia G, Antala S, Madan M, Javdeker T. 2011 - Microbial keratitis in Gujarat, Western India: findings from 200 cases. Pan African Med. J. 10(1), 48-56.

Lado C. 2001. - Nomenmyx. A nomenclatural taxabase of Myxomycetes. Madrid.

Lakhanpal TN, Mukherji KG. 1981 - Taxonomy of the Indian Myxomycetes. J. Cramer, FL - 9490 VADUZ, 01-411.

Lodhi SA. 1934 - Indian slime molds (Myxomycetes) (Being Descriptions of the species collected by Late Mrs. Drake) University of Punjab, Lahore, reprinted by: Sushma Publications 318 A, Dehradun (1981), 1-34, Plate I - XVII.

Martin GW, Alexopoulos CJ. 1969 - The Myxomycetes. University of Iowa Press, Iowa City.

Martin GW, Alexopoulos CJ, Farr ML. 1983 - The Genera of Myxomycetes. Univ. Iowa Press, Iowa City.

Nagadesi PK, Arya A. 2012 - Lignocellulolytic activity of wood inhabiting fungi from Ratanmahal Wildlife Sanctuary Gujarat, India. Adv. Biotech. 12(5), 3036.

Nagadesi PK, Arya A. 2013 - Rotting of Peltophorum ferrugineum (Decne.) Benth. by pathogenic lignicolous fungi in Rajpipla, Gujarat, India. J. New Biol. Repo. 2(1), 17-27.

Nasit J, Sojitra N, Bhalra R, Gauravi D. 2013 - Aspergillosis of bilateral breast and chest wall in an immune-competent male masquerading as breast cancer. Intl. J. Health \& Allied Sci. 2, 212 215.

Nawal P, Patel S, Patel M, Soni S, Khandelwal N. 2012 - A study of superficial mycoses in Tertiary Care Hospital. Nat. J. Integra. Res. Med. 3(1), 90-93.

Panchal P, Pethani J, Patel D, Rathod S, Shah P. 2013 - Analysis of various fungal agents in clinically suspected cases of otomycosis. Indian J. Basic \& Appl. Med. Res. 8, 865-869.

Rajput KS, Koyani RD, Patel HR, Vasava AM, Patel RS, Patel AD, Singh AP. 2015 - A preliminary checklist of fungi of Gujarat State, India. CREAM J. 5(4), 285-306.

Ranade VD, Korade ST, Jagtap AV, Ranadive KR. 2012 - Checklist of Myxomycetes from India. Mycosphere DOI: 10.5943/mycosphere/3/3/9

Saxena RK, Ranhotra PS. 2009 - Palynofloral study of the intertrappean bed exposed at a new locality in Kutch District, Gujarat and its implications on palaeo-environment and age. J. Geol. Soc. India 74, 690-696.

Sesli E Denchev CM. 2008 - Checklists of the myxomycetes, larger ascomycetes, and larger basidiomycetes in Turkey. Mycotaxon 106, 65-67.

Shah BP, Chauhan D, Shah -DR, Chauhan P, Shah RR. 2013 - Seasonal variation of airborne microflora in dairy processing plant. Species 2(6), 18-22.

Singh S, Beena PM. 2003 - Profile of dermatophyte infections in Baroda. Indian J. Dermat. Venere. Leprol. 69, 281-283.

Spiegel FW, Stephenson SL, Keller HW, Moore DL, Cavender JC. 2004 - Sampling the biodiversity of mycetozoans. In: Mueller GM, Bills, G. and Foster, M. S. (eds). Biodiversity of Fungi: Inventory and Monitoring Methods. Elsevier Academic Press, Burlington, Massachusetts. p. 547-76. 
Thaker S, Maharsh R. 2012 - Growth and development of plant pathogenic fungi in define media. European J. Expt. Biol. 2(1), 44-54.

Thind KS. 1977 - The Myxomycetes of India. Indian Council of Agricultural Research, New Delhi, page no. 1-452.

Yadav SM, Patil RK, Rai AK, Balai LP, Singh S, Niwas R. 2013 - A survey: Occurrence of postharvest rot of aonla and new reported pathogen (Penicillium funiculosum Thom.). Plant Pathol. J. 12(2), 124-126. 